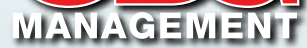

\section{SPECIAL SECTION}

\section{THE 2020 SGIENTIFIC MEETING OF THE SOGIETY OF GYNECOLOGIC SURGEONS}

\section{HIGHLJHTS ISSUE, PART 2}

\section{Marc Beer \\ Boston, Massachusetts \\ Chairman of the Board, Origami Surgical \\ Madison, New Jersey \\ Chairman of the Board, LumeNXT \\ Boston, Massachusetts \\ Chairman of the Board, Liftique, Inc. \\ Newport Beach, California}

Chairman and Chief Executive Officer, Renovia, Inc

\section{Patrick J. Culligan, MD}

Co-Director, Urogynecology

Valley Hospital System

Ridgewood, New Jersey

Professor, Gynecology \& Urology

Weill Cornell Medical College
New York, New York

\section{Kristie Greene, MD}

Assistant Professor, Female Pelvic Medicine and Reconstructive Pelvic Surgery

Department of Obstetrics \& Gynecology

University of South Florida Morsani College

of Medicine

Tampa, Florida

\section{Sally Huber, MD}

Urogynecologist

Advanced Gynecology

Atlanta, Georgia

\section{Catherine Matthews, MD}

Professor, Female Pelvic Medicine and Reconstructive Pelvic Surgery

Departments of Obstetrics \& Gynecology and Urology Fellowship Director

Co-Director, Integrated Pelvic Health Unit

Wake Forest University Baptist Health

Winston Salem, North Carolina

\section{Charles Rardin, MD}

Professor, Obstetrics \& Gynecology

Warren Alpert Medical School of Brown University

Chief, Surgical Operations

Women \& Infants Hospital

Providence, Rhode Island 
ROUNDTABLE

Work-life balance:

How 5 surgeons manage life in and out of the operating room

\author{
Balancing work, home, and family is an acquired skill. Here, \\ your colleagues offer their best advice based on their own trials \\ and triumphs.
}

\author{
Expert panel featuring Patrick J. Culligan, MD; Kristie Greene, MD; \\ Sally Huber, MD; Catherine Matthews, MD; and Charles Rardin, MD
}

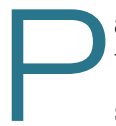

atrick J. Culligan, MD: We all know that burnout is an important problem among surgeons. In fact, it seems that, in the United States, we are working longer hours than ever before, and that higher education correlates with less balance in life. This dysfunction seems to start in school, when we are encouraged to be competitive, and overwork just becomes another way to compete. It's very easy to get swept up in the traditional model of academic medicine, the engine of which is competition and overwork.

My impression of our younger colleagues, however, is that many of them are not attracted to the traditional ivory tower research model of academic advancement to which many in previous generations aspired. They seem more concerned with work-life balance as their measure of success rather than the classic metrics of money and prestige. Everyone still needs role models and mentors, though, and that's where all of you come in. I asked each of you to be on this panel because I admire you for your varying approaches to worklife balance while achieving success as gynecologic surgeons. I thought others in the field might be inspired by hearing your stories.

\section{Cultivating your passions}

Kristie Greene, MD: What I have come to learn and appreciate is a really simple point: you do not have to do everything. Determining who you want to be both personally and professionally is step 1 .
Granted, answering the question, "Who do I want to be?" is not as simple as it sounds. Many factors figure into the decisions we make in our personal and professional lives. Also, it is not a question we often stop and ask ourselves. From early on, we are placed on an escalator moving up through medical school, residency, fellowship, good job, better job, etc. We are so accustomed to being competitive, to winning, and to wanting to be the best that we sometimes forget to ask ourselves, "What is it exactly that I want, and why? What is my endpoint? And does it make me happy?"

Multitasking is regarded as a talent. As much as we would like to believe that we can do everything at the same time and do it all well, we actually can't. A friend of mine made me read a book a couple of years ago, called Feeling Good, by David Burns. The book encourages you to consider the different tasks you do in a day and rate how good you are at each of them on a scale of 1 to 10 . It then asks you to think about how much enjoyment you derive from each of the tasks and about why you are doing the ones that bring you little to no enjoyment.

I ultimately decided that, for me professionally, the most important thing was my interest in global health. So I decided to do whatever it took to make this happen. But you don't get something for nothing, and everything comes with sacrifices.

Charles Rardin, MD: How exactly did you decide that you were going to focus your career toward pursuing international health? How did you know it was more important? And how did you overcome some of those obstacles? 
Dr. Greene: You have to ask the hard question again about what brings you the most joy professionally and personally. That was the easy part of it for me because global health has always been that source of happiness and fulfillment for me. The more challenging parts are the sacrifices and hard choices that come with it. With global health, it can be difficult to balance the demands of a clinical practice.

All of our jobs are a business. I am still struggling with the money part of it. For my husband and I, that meant we had to start small-do what we could afford. But then it blossomed into something that was involving residents, fellows, and med students, which requires far more funding than we had. So I reached out to family. Most of our families donate to different organizations or charities every year, so why not donate to a loved one for something they are passionate about?

At the University of South Florida (USF), we set up a fund, a foundation for global health, which helps support our work abroad as well as the costs associated with involvement of our trainees. Right now, what we have is still small potatoes to a country, but we are making it happen by starting at a small level and growing it.

Beyond the money aspect, traveling abroad means less involvement in meetings, missed opportunities to teach courses that might interest me, and time away from my family. I guess my advice on this whole thing is that you can make things happen if they are important enough to you, and if you are willing to make sacrifices in other areas because you can't have it all.

\section{Making time for you}

Dr. Culligan: So you have found what is important to you, and you have found a way to make it happen. But you are faced with more work; you have given yourself additional work on top of your regular work. How do you make time for a personal life?

Catherine Matthews, MD: In preparing for this discussion, I decided to break down my advice into 3 buckets: The first bucket is discovering and knowing your authentic self. The second is building a community, which I'll elaborate on. And the third, which we have discussed, is to let go of the money.
Dr. Culligan: I love the concept of the authentic self, but how does that jive with a tendency to strive for perfection? We all think we can do it all. How do we narrow down to what really matters?

Dr. Matthews: We often focus on the things that bring us happiness and what we are good at, but it's the things that make us unhappy that tend to bring us down. It's the presence of unhappiness, not the absence of happiness, that seems to be the undoing of many, including myself.

\section{OBg MANAGEMENT EXPERT PANEL}

\section{Patrick J. Culligan, MD}

Co-Director, Urogynecology

Valley Hospital System

Ridgewood, New Jersey

Professor, Gynecology \& Urology

Weill Cornell Medical College

New York, New York

\section{Kristie Greene, MD}

Assistant Professor, Female Pelvic Medicine and

Reconstructive Pelvic Surgery

Department of Obstetrics \& Gynecology

University of South Florida Morsani College of Medicine

Tampa, Florida

\section{Sally Huber, MD}

Urogynecologist

Advanced Gynecology

Atlanta, Georgia

\section{Catherine Matthews, MD}

Professor, Female Pelvic Medicine and

Reconstructive Pelvic Surgery

Departments of Obstetrics \& Gynecology and Urology

Fellowship Director

Co-Director, Integrated Pelvic Health Unit

Wake Forest University Baptist Health

Winston Salem, North Carolina

\section{Charles Rardin, MD}

Professor, Obstetrics \& Gynecology

Warren Alpert Medical School of Brown University

Chief, Surgical Operations

Women \& Infants Hospital

Providence, Rhode Island

The authors report no financial relationships relevant to this article. doi: 10.12788/obgm.0038 
CONTINUED FROM PAGE SS3

None of us are born with dramatic insight. It is experience that leads to insight. People who are actually present are able to gain insight through observation. A person becomes a better surgeon by observing the outcome of doing a stitch this way versus that; you learn how to do it by seeing what it looks like afterward.

Finding our authentic selves happens in much the same way. Having the presence of mind to ask the right questions, such as, "How am I feeling while I'm doing this?" leads to insights into the true self.

\section{It takes a village}

Dr. Greene: Catherine mentioned community earlier, and that is extremely important. The people who surround us can have a huge impact on the way we perceive things, including ourselves. Having a mix of people in our lives-some who practice medicine and others who don't-helps us stay balanced and answer some of the tough questions. Catherine, for example, has helped me in various stages of my career to ask myself meaningful questions and get real answers.

Dr. Rardin: Part of finding balance is luck, and part of it is making a choice between money and everything else. In considering my first job out of training, I knew that money had the potential to distract me from what was important to me. So I chose a position that was almost entirely salaried so that the decisions I made clinically, surgically, and regarding work-life balance would be less likely to directly impact what was important to me. Sally Huber, MD: I am still in the "getting there" phase of my life, but one thing I have found is that getting my family involved and excited about what I do has made them much more accepting of when I have longer work days or work to do on the weekend. My spouse has become quite involved with what I have been doing with transgender health in Atlanta. It has been a great bonding experience; she shares my passions, and together we are creating something about which we both can be proud.

\section{When work invades home life}

Dr. Culligan: That is great. Sally, I think when we talked, you were just learning about the necessity of mental separation and of not taking your work home with you, which is so hard for all of us with all of our devices.

Dr. Huber: Yes, this year has been about seeing what works best as far as being efficient at work and having quality time at home. At the end of every day I ask myself, "What worked well today? What didn't work well? What else can I do to maximize time with my family?" I am slowly becoming more efficient, but it has been a challenge. During fellowship, your day is pretty set, but once you are practicing on your own, your hours and responsibilities are completely different, and you have to figure out what works best for you, your values, and your expectations of private life. It takes some time, and I am still figuring it out.

Dr. Culligan: How often would you say that you bring work home? I try hard once I am home to quit working, but sometimes on the weekends I break that rule.

Dr. Matthews: I must say that I do feel like there are certain times when I am better at that than others. Work comes in waves with pressing deadlines. If I averaged it out, probably a third of the time I have some email or some conference call or something that I have got to do at home. I do really try to limit the obligations that I have after 5:30 or 6:00 pm. I resent intrusions after that time. As far as weekends, I delegate about one weekend every 2 months to work, instead of doing a little bit every weekend.

Dr. Greene: I agree. I try hard to make 5:30 to 7:30 pm unequivocal time for a family dinner and time for my kids. During that time, I do not have my phone near me so I can't look at email or texts. I try not to schedule conference calls. I try to be there to read books to my kids at night. Then if I need to do work, I do it later at night, which interferes with time with my spouse, and is not ideal, but that's what happens.

Dr. Matthews: One of the things that I think is a huge part of work-life balance is work-related travel. When you are present at work on a consistent basis, the work does not pile up to the extent that it does when you are absent on a trip. When you come back, you invariably pay the price by seeing more patients and doing more surgery. Then it becomes a stressful event.

My advice to young people is to be very thoughtful about planning trips, especially distant ones. You do not want to sit on a plane all day 
when you could be doing something more productive. If I could have done something differently in my mid-career, I would have traveled less.

\section{Prioritizing "out of office" time}

Dr. Greene: How do you all mentally separate yourself from work, so that when you are on vacation with your family you are not thinking about the office, the patients, and all of the things on your to-do list?

Dr. Rardin: I don't have a great answer for that except that it is about being present. You have to decide that now is the time when I am home, now is the time when I am a parent, now is the time when I am a boy scout leader, etc. I guess maybe it's a skill, or maybe it's about making something a priority. Work will always be waiting for you when you turn your attention back to it.

Dr. Matthews: Kristie, the answer to your question goes back to community. Partners in a practice cover for each other. You have to trust them to take care of things so that you can relax during your time away.

Some people recommend not scheduling challenging cases right before going away because invariably something goes wrong, and then you are asking, "Why did I schedule 3 colpopexies before getting on a plane?"

Dr. Rardin: Yes, I completely agree with all of that. Personally, I feel fortunate that I can compartmentalize pretty well. When I am home with my kids, I allow myself to shed some of the doctor/surgeon/ leadership persona; I am able to be goofy and completely non-doctor-like. It works to help me leave work behind.

Dr. Matthews: Other things you can do include setting up an out-of-office notice on your email that says when you will be back and what to do in case of urgent matters. This basically says to the world, “Don't expect to hear from me until X date." It removes the expectation that you will respond sooner. Otherwise, we would all be on our smartphones all the time and not enjoying our time away.

\section{What I wish I knew then}

Dr. Culligan: How would you complete the sentence, "I wish they had told me X when I was embarking on my career?"
Dr. Rardin: I keep coming back to the phrase, "Don't do anything that you can reasonably pay someone else to do." By that I mean, if you don't get energy from housework, consider spending some of your money to get help with the housework. Resolve to make a relatively small expenditure to maximize the quality of the time that you give to yourself and your family. Those are the sorts of things that I think can go a long way.

Dr. Culligan: Charley, your wife is an ObGyn. How do you navigate a dual medical career household? What advice do you have for others?

Dr. Rardin: When I was going into fellowship, we had a conversation about how hard it is for both people in a relationship to have an academic fire in the belly and to be truly engaged in climbing the academic ladder. We made a decision that Jane would go into private practice. There has got to be some give and take in a dual medical relationship; a lot of sacrifices and compromises need to happen. We are fortunate in that there are complementary aspects to our jobs. We both spend about the same number of nights away from the house, but my travel is more in chunks and hers is overnight calls for labor and delivery. We have different ways of (briefly) single-parenting, and you have to come up with ways to handle the domestic chores. Dr. Matthews: I wish someone had explained to me that the people you work with are much more important than the place. The human connection is what defines your experience, much more than any ego-driven outcome.

Dr. Greene: I wish someone had explained to me the competing aspects of academic medicine. The cards are stacked in a way that make it difficult for you to win. For example, you may love to teach and may be really good at it, but if you let your students handle too many cases, your relative value units plummet and then the hospital is on your back. There are the interests of people, and there are the interests of the business. Everything is a balance, and it's really tricky.

Dr. Huber: Luckily, Pat counselled me as I was finishing my fellowship about the importance of negotiating a good contract, of being pushy and knowing what you want out of it and knowing what your limitations are. I joined a private practice that had 3 different physical locations. If I had to drive to all of them, as they wanted, it would have meant up to a one-and-a-half-hour commute. But 
I pushed to stay in one location and to put that extra hour to better use. I am glad I did, but it was terrifying at the time because I didn't want to lose the offer. I know people that did not do that and took the first thing they got. Now, they are driving all over the place or they have these crazy hours or terrible call responsibilities that if they had just been a little firmer, they probably could have gotten out of. As they start trying to find work-life balance, they are already handicapped.

\section{Passions outside the office}

Dr. Culligan: One thing I would like to touch on is what is going on in each of your personal lives because all of you have interesting stories to tell outside of what you do professionally. What drives you other than medicine?

Dr. Rardin: I am the father of 3 boys. The oldest one just got his Eagle Scout rank yesterday in Boy Scouts. I would be a woodworker if I wasn't in medicine. I am a Deacon at church. And I love to spend my downtime reading with my family in front of the fireplace.

Dr. Matthews: For me, it's music. When my husband and I first met, he asked me if I played a musical instrument. I said I played the cello in primary school. He said, "Great, go rent a cello." I was never at all interested in playing the cello by myself, but because he plays guitar and piano we became able to play a lot of music together. Our son, Alexander, plays drums. We now have a family band.

In addition, I doyoga. I would never havelabeled myself an anxious person, but I learned through this process that I am and need to manage it. It took a lot of years to figure that out. If I don't leave myself an hour each day to go to a yoga class, I am not a happy person and neither is anyone around me. Also, I get tremendous pleasure from reading books and magazines as opposed to watching a screen.

Dr. Greene: I have found that my passions outside of work often change depending on my stage of life. Right now, I have two young babies and so my life outside of work revolves around them. Before the babies, my dad, who lives in Buffalo, was ill. So for awhile, we were flying to Buffalo almost every weekend that I was not on call. I would say, in general what fuels me is connecting with the people I love as often as I can. A typical night involves me and my husband going for a walk with our kids and dog after dinner and talking to each other. We connect with neighbors and chat on the front porch. It doesn't really matter what we are doing; it is about being surrounded by people who matter.

Dr. Huber: It's similar for me. Having a child completely shifts your world view. My goal every day is to give my daughter her first feeding in the morning and to get home as soon as possible at the end of the day to do her last feeding and put her to sleep. She crawled for the first time yesterday, and I was so excited that I could be there for that.

Also, I love being outdoors. I love hiking and camping. Going on a hike and being outside with nature is my way of decompressing.

\section{Thinking about upcoming generations}

Dr. Matthews: One other thing I would like to propose is looking at what can we do to make the profession better for the next generation. As a group, our profession is somewhat inflexible. We tend to fall into the trap of, "since this is the way we have always done it this is how we should continue doing it." The OR still starts at 7:00 or 7:30 am, ignoring the need for school drop-offs, etc. We are not innovative about flexibility in the work week. Honestly, it does not work well for many people, patients and physicians alike. Flexible scheduling should be something that is on the table for both men and women who are trying to balance being full-time parents and full-time surgeons. We need to create an environment in which it is okay for you to spend 10 years instead of 6 as an assistant professor because you are also a young parent, and it will not count against you when you come up for promotion.

Dr. Culligan: I agree with you, Catherine. Full "Professor" is a nice title, but it means time away from family and a lot of other things. Each of us has to decide whether it is worth it, especially since it often does not come with any extra money.

Dr. Huber: A question on a recent survey of residents asked, "Do you see yourself going into private practice or academic medicine when you've completed your residency?" When I was a resident, everyone wanted to go into academic medicine, but now it seems like more and more residents have their sights 
CONTINUED FROM PAGE SS6

set on private practice because that is where they see the opportunities to create work-life balance.

In the academic world, you have to try to get a promotion in X number of years, and get $\mathrm{X}$ number of publications, and be a great teacher, doctor, and administrator all at the same time. I am wondering if we are going to start seeing more and more residents and fellows going into private or hospital-owned practice where there aren't those added expectations.
Dr. Rardin: I agree, and we are back to what we said in the beginning about doing an honest assessment of what is meaningful and important. We are all trained to try to reach for that shiny brass ring, but do we really want that brass ring? Will it be an asset or a hindrance once we get it? It is okay to be honest and say, "I really don't want that promotion. I would rather spend more time with my family." 
BRINGING YOUR IDEAS TO MARKET

\title{
The professional advancement of drug and device innovation
}

\author{
This entrepreneur offers his past paths to success, as well as \\ bumps to avoid, while taking a product or drug development \\ from an idea to standard of care
}

\section{Marc Beer}

\begin{abstract}
often say that there are both "guardrail" days and very good days when it comes to the ins and outs of health care builds and product launches. The process is much like starting down the path of a country road in the middle of a blizzard-unless you have dependable wipers and a good defrost system, that path can get murky very quickly. With this article I hope to offer my counsel to inventors, featuring a few of my prior launches as well as case studies of health care launches I was not involved with, and sharing the lessons learned and hurdles that were overcome. I encourage all entrepreneurs to act on their ideas because, in the world of health care startups, the only failure is not acting on an invention.
\end{abstract}

\section{Case study 1: Cerezyme}

Today, Cerezyme is indicated for patients with Gaucher, which is a lysosomal storage disorder. Cerezyme's first-generation product, called Ceredase, was a human tissue-derived protein that we extracted from human placentas. At the time, the concept of moving this program forward was denied by the Board of Directors because they said that even if you could collect enough placentas to make the enzyme, it would be too expensive to manufacture. In fact, early scale-up modeling for manufacturing the protein demonstrated

The author reports being an equity holder in the following companies: Renovia, Inc; Origami Surgical; LumeNXT; and Liftique, Inc.

doi: 10.12788/obgm.0039

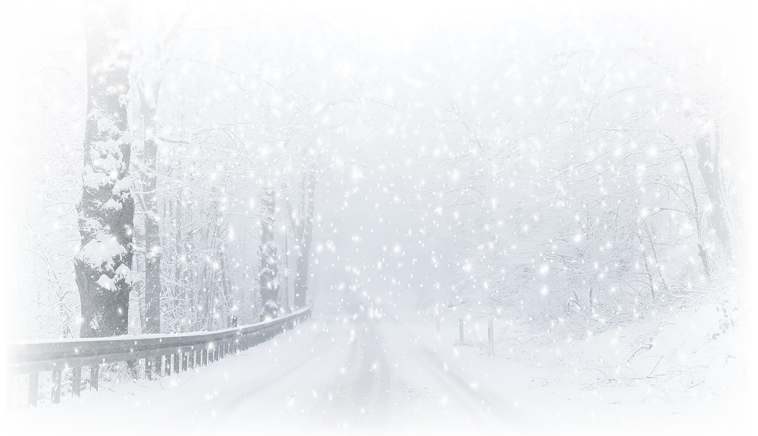

that Genzyme would need 4 tons of placentas per Gaucher patient per year.

Gaucher is a severe, early-onset disease that has a significant negative outcome for patients. $\mathrm{Pa}-$ tients with Gaucher are in dire need of treatment. Genzyme went forward with the Ceredase program by financing it through the families of patients with the disease, by starting an LLC separate from the business and funding the initial clinical trial and the development of the protein through the families of Gaucher patients. That approach was a successful endeavor. A great example of a creative capital structure to advance a program.

This was in the late 1980s/early 1990s, and at the height of the AIDS challenge. Genzyme based the manufacturing in Lille, France, and we cryopreserved placentas in the United States and Europe and shipped them to Lille to be processed into therapy. Genzyme eventually received approval for Ceredase from the US Food and Drug Administration (FDA) and the European Medicines Agency. At the height of the placenta collection, we were gathering about $10 \%$ to $15 \%$ of the 
placentas in the United States and $30 \%$ to $40 \%$ of the placentas in Europe. Resources supply became an issue until we developed a recombinant form of the protein, accomplished by using a manufacturing system called a CHO cell line.

This is a very good success story: If this invention was not pursued, Gaucher patients would not benefit from the treatment today. In addition, there are a plethora of patients with different lysosomal storage disorders treated with additional proteins that have been aided by us going through the entire development, manufacturing, and global commercialization process. We figured out how to manufacture and deliver the treatment, working through multiple countries' political systems, and today the therapy is paid for by insurance and government systems on a worldwide basis.

\section{Case study 2: ThinPrep}

I like to use the approval of ThinPrep as an example of avoiding a false negative-a stoppage in the development of the product or drug for the wrong reasons. False negatives, in my mind, occur when you are developing a technology and you run into issues during the clinical phase and/or with FDA approval, or with a technical failure or you run out of capital prior to knowing whether or not the innovation actually works. In the case of ThinPrep, a poorly run clinical trial almost resulted in a false negative.

The company at the time was Cytyc, and an initial clinical study presented to the FDA yielded a neutral-negative outcome. The FDA said that there were not enough data to show the differentiation from the current Pap smear standard of care.

The founders of the company at that time had inherited the study protocol from a prior leadership team, so they had to finish the trial with the initial protocol. Given the FDA's advisement, they developed a new trial. It took the persistence of these two founders, who mortgaged their homes and spent their personal dollars to take this through the next wave of clinical development. In the end it was successful. The revised clinical trial yielded an approval for ThinPrep, which is now considered a standard of care.

The use of ThinPrep reduced cervical cancer deaths by $40 \%$ from preapproval. The challenging path from clinical development to eventual com- mercial launch and physician leadership in advancing patient care makes the story of ThinPrep a great example of not allowing an early false negative of a poorly designed and run clinical trial stop important innovation.

\section{Case study 3: Cologuard}

The development of Cologuard is a case study demonstrating that, sometimes, when your first attempt does not work, you need to have the persistence to raise additional capital and/or use a slightly different technical approach. The approval story of Cologuard is important to share because it is an important cancer screening diagnostic, using DNA from stool samples to test for colon cancer, giving access to important colon cancer screening to many patients. Currently, caregivers are only scraping the surface with Cologuard's ability to screen the population. There are many more patients that need access to the test, and I believe they will get it in the years ahead.

Cologuard went through a first- and secondgenerational technical failure. They could not get the test's specificity and sensitivity to be at the level of a screening tool; there were too many false-positive results. With the third iteration came the technical breakthrough, and a very large, expensive study was conducted-one the leadership team was criticized for. However, that study yielded the data that achieved a New England Journal of Medicine article, and reimbursement support across the country. The combination of the right technical team and the right leadership team, who planned a proper commercial launch, with a CEO that supported the extensive clinical study, has resulted in the fourth generation of Cologuard-an important breakthrough offering a very useful new standard of care in colon cancer detection and screening.

\section{Pearls for moving your innovations forward}

Because of my experience in undergoing health care start-ups, and contributing to several of those advancements of innovation, many inventors approach me for advice on their paths from idea to full-concept company. Here are a few of my lessons learned. 
Consider purpose, not financial gain, first and foremost. Financial gain is typically the by-product or outcome of a standard-of-care breakthrough for inventors, but it's a very hard road. Pursue your invention for advancing patient care and moving a new standard of care forward in health care versus financial gain at the end.

Determine whether your invention is a product or a company, or potentially, not capitalizable at all. Figure this out early. Analyze your idea to make sure it is sound and truly novel. Analyze the competition and to make sure it is sound and truly novel. Analyze the competition and the market dynamics to support a new product. Can the development path be defined very clearly to raise capital? Is your innovation a big enough breakthrough in the market with several current products to actually make a difference in patient outcomes (and eventually achieve product reimbursement)? The creation of a company may be the right strategy if the innovation can support a differentiated enough breakthrough where you can actually support all the infrastructure to build the business. If you find that the market is not there to support and develop your idea to eventual success, backing off early is important to preserve invested capital.

Protect early. Is your invention patentable, or has someone else already thought of the idea? What kind of patent(s) are appropriate? Where, geographically, do you want to protect your invention? Find a good patent attorney in your local area, early in the process, to help you answer all of these critical questions. Patents are expensive to file and maintain, but it is not expensive to do a literature search to find out if your idea is novel. A provisional patent, which would be your first step, is an important cost-effective step.

Capital is out there. If your invention or idea deserves capital, it is available. I will address raising capital in more detail in the next section.

Consider regulatory and manufacturing as achievable hurdles. Inventors often get tripped up here, considering the regulatory hurdles and manufacturing too challenging and abandoning their ideas because the risk is too great. Regulatory and manufacturing are very important aspects of health care standard-of-care builds. Cutting corners is not an option. That said, regulatory and manufacturing should not stop you.
Challenges often can be worked through as long as the clinical need is there, and the clinical data support bringing that technology forward.

Consider corporate partnerships. I am a fan of corporate partners. But which ones should you target, and when and why? Corporate partnerships can bring significant capital, which is great, but there is enough investor capital out there that you should not pursue a corporate partner just for capital. The main benefit of a corporate partner is enterprise intellect. They typically know more about the field that you are entering than the investors or a small company leadership team.

Establish and listen to advisors. When thinking about who to trust, research their track record. Advisors who have gone through this process before, and specifically in your product area, are important to have access to.

Persistence is key. I have observed a tremendous "compression of innovation" in the health care areas that I have been involved with-human tissue-derived proteins, robotic surgery, stem cell therapy, and digital health (which is still in its infancy). For each of these breakthrough categories, early on, it appeared that it couldn't be done. However, after the first 2 or 3 major breakthroughs in each one of these areas, a compression of innovation occurred. For instance, after approximately 15 years of protein development, we came out with the recombinant manufacturing systems for proteins. Very quickly, within 10 years, there were more than 70 proteins on the market. The persistence of the inventors to overcome early obstacles in each of these health care areas was critical to future success in each area.

\section{Raising capital}

There are different investors who specialize in different types of investment opportunities. The first phase of raising capital is the seed round-where there is typically early data, or even no data and just a concept. From this seed round forward, there is less risk as you develop your technology; thus, there are different investors that support different stages of development and that specialize in different types of investing. It is important to target the right investors and raise enough capital to be able to go achieve multiple operational milestones. 
CONTINUED FROM PAGE SS11

Otherwise, when you go through your first round of capital, or the Series A or B financing rounds, there may not be a set of investors out there to fund the company moving forward. Health care investors will make it known that they invest in certain rounds of capital. You can determine who those investors are by doing a search online.

A mistake health care inventors can make is not taking enough capital from investors, because they are concerned about dilution. I advise investors not to focus on dilution but rather on, how big can you make "the pie" (value of the company) worth? The entire process is about bringing a true product through to a new standard-of-care curve.

Trust is the most important thing to earn with investors, and there is zero tolerance for a lack of trust. Share your vision as the inventor with investors, who want to know where this category could be in the next 5 or 10 years. Clinical data will always win, and health care investors and industry leaders should be focused on executing the most robust clinical data to demonstrate the clearest potential clinical outcome. Investors will follow a good plan that has been developed to achieve FDA approval, successful commercialization or "go to market" launch, and eventual reimbursement to support a true standard-of-care change.

\section{Failure is defined by inaction}

The 3 case studies that I have shared were success stories because the ideas and inventions were acted upon. When I was at Genzyme, we built the company up to more than $\$ 1$ billion in revenue. We commercialized proteins in over 50 countries. Most importantly, many patients benefited from the innovation. If you have an invention and an idea, act on it-and surround yourself with great people in every discipline. Having the right people and team is extremely important. 